\title{
Torsadogenic Index: Its Chinese Medical Origin
}

\author{
Adrián Ángel Inchauspe $e^{1,2,3,4,5^{*}}$ \\ ${ }^{1}$ Scientific Department, Argentina Acupuncture Society, Buenos Aires, Argentina; ${ }^{2}$ Argentina Resuscitation Council, Buenos Aires, \\ Argentina; ${ }^{3}$ Investigation Department, HINEA y C. "Dr. Alejandro Korn”, Melchor Romero, La Plata, Argentina; ${ }^{4}$ Medical Sciences \\ Faculty of La Plata University, La Plata, Argentina; ${ }^{5}$ Chronic and Acute Care Neuropsychiatric Hospital Interzonal "Dr. Alejandro \\ Korn”, Melchor Romero, La Plata, Argentina. \\ Email: adrian.inchauspe@yahoo.com.ar
}

Received July 20 ${ }^{\text {th }}$, 2013; revised August $21^{\text {st }}, 2013$; accepted September $8^{\text {th }}, 2013$

Copyright (c) 2013 Adrián Ángel Inchauspe. This is an open access article distributed under the Creative Commons Attribution License, which permits unrestricted use, distribution, and reproduction in any medium, provided the original work is properly cited.

\begin{abstract}
The foundational chronology of Torsadogenic Index is introduced to explain the relationship between impending death situations and drug prescription, combination, self-indication, or abuse of torsadogenic pharmacological products. The pathophysiological basis of Torsade de Pointes is presented with the most frequent causes of Long QT syndrome. Traditional Chinese Medical principles are exposed in order to help people to understand its para-logical sequence, providing another view of medical explanations upon scientific evidence. Development of Torsadogenic Risk Management Project and Torsadogenic Traceability concepts derived from these Chinese Medical perpetual axioms are presented in this paper.
\end{abstract}

Keywords: T. Index; TCM Principles; Scientific Evidence

\section{Background}

Invited by the Chinese Government to the 8th BIT's International Congress of Drug Development, Science and Technology, I assisted to the Overture Ceremony in the Beijing International Convention Center [1].

In Expert's Presentation, I met Dr. Jufeng Wang, for that times Chief of the Exploratory Office of Toxicology in Harvard. During his interesting dissertation [2], he announced several medications that derive into sudden death for electrocardiographic QT interval prolongation. Deeply impressed, I returned to Argentina wondering how many impending death situations could be referred to patients that had previously taken drugs.

Back at work, I asked Dr. Wang for a complete list in order to prevent its dangerous consequences. With great surprise, 80 pharmacological products of common use appeared as potentially cardiac arrest threatening risk [3]. All of them lead to death for the same reason: the development of a menacing arrhythmia called Torsade de

\footnotetext{
*National Delegate for the 5th International Conference on Drug Discovery and Therapy 2013, Dubai, United Arab Emirates; National Delegate from Argentina in Ninth International Brain Injury Association Congress, Edinburgh, UK; Editorial Highlight Member of the World Journal of Critical Care Medicine, Ed. Baishideng, Beijing, China; Editorial Guest Member of Frontiers of Clinical Pharmacology Research and Outcomes Journal, Basilea, Switzerland.
}

Pointes (TdP) [4,5].

\section{Introduction}

Torsade de Pointes is a potentially tachyarrhythmia capable to progress into ventricular fibrillation, a major cause of heart arrest [4].

Long QT syndrome appears due to genetic mutation (Congenital LQTS) or secondary causes (Acquired LQTS) as [5]:

- Bradyarrhythmias: sinusal arrhythmia-sinus bradycardia-AV block;

- Metabolic abnormalities;

- Drugs;

- Central Nervous System's injuries: thalamic hematoma-subarachnoid hemorrhage;

- Hidroelectrolitical disturbances;

- Malnutrition-anorexia nervosa-liquid protein elemental diets.

\section{Physiopathology}

This TdP condition is caused by an ionic channel dysfunction in cardiac cells membranes [5].

It occurs due to blocking potassium efflux or excessive sodium entry in cardiac cells, causing intracellular positive ion's overload that delays ventricular repolarization, 
facilitating early depolarization [6].

\section{Material}

After obtaining the suspicious drug list, I began spreading this knowledge in order to mitigate risks. First conference took place in La Plata Children's Hospital; and its personnel kept in touch with me, consulting about pharmacological indications over quoted drugs.

From this group of patients was extracted the case presented in Torsadogenic Index: a proposal to improve survival rates in cardiac arrest due to prescribed drugs [7].

From the beginning, this impending death situation was analyzed under Traditional Chinese Medicine (TCM) principles, founding its reasons in its ancient intricate relationships [8,9].

Quoted case in Frontiers of Medical Pharmacology Research and Outcomes was a one-year-old infant with acute lymphocytic leukemia under oncological treatment with vincristine, daunorubicin and pegylated asparaginase-MARMA Interfant 05 IB protocol-prescribed in a particular season and in a specific hour of the day [7].

These facts, almost irrelevant for Western medical science, are crucial to understand the following consequences that finished in the cardiac arrest of this child [8].

\section{Method}

A chronological sequence shows quoted cases characteristics that lead to conclusions according to TCM view.

First of all, TCM developed the Five Movements Theory for explaining a Cosmological order; the harmony in human nature and-in our bodies - their organs and viscus relationships. This Five Elements' Principles remind me the Euclidian Geometry's Axioms. It's not by chance that Euclid explained Universe's structure based upon its Five Regular Polyhedrons, naming them in the same way as Chinese masters did.

In particular, reference to Wood element, it's compound by Liver — as its organ; and Gallblader —as its viscus. Unlike in Water, where patient condition "falls down" as it gets worse-like in a cascade, Wood pathologies behave like flames: as condition get in progress, the "burning state" is more serious over the patient; "and the flames grow up".

Oncological drugs-vincristine, pegylated asparaginase and daunorubicin-even administrated in correct prescription and doses-have notorious hepatotoxic adverse effects.

This condition is called "Toxic Heat"; and over the Liver_a Wood zhang — may provoke an "ignition" that puts this organ in serious functional danger.

Furthermore, medication was administrated in Summer-a Fire season; another reason that make Liver-as a Wood organ—vulnerable to flames [10].

Finally, treatment was accomplished at 12:30 a.m.: very near the most Yang hour, and sun plenum clarity and heat.

Synthetically, under Traditional Chinese Medicine's view, this child received its hepatotoxic medicines ("Toxic Heat"); in Summer ("Fire station”); and at mid-day (“Fire hour").

Quoted deductions about this summary of conditions that affected Heart - the next organ in TCM's "Mother and Son Rule" - is based upon Cheng Generation Cycle that allows a creative sequence between the Five Elements in Chinese Medicine.

Heart is the "Son" of Wood; so that "Toxic Heat" damaged it so seriously, that cardiac arrest was the corollary of this accursed example.

\section{Results}

As quoted in Frontiers journal, oncological drug plan was scheduled with a week-interval between drugs; and this kid had a successful treatment and kept alive [7].

Downloaded by more than 500 subscriber experts; Frontiers editorial considered Torsadogenic Index's Impact Factor as one of the most impressive of this prestigious journal.

Invited as speaker to 5th Drug Discovery and Therapy Dubai conference and last 5th World Drug Discovery Congress in Boston, made me possible to introduce new Drug Risk Management Project [11] and Torsadogenic Traceability Concept [12] for reducing death rate due to drug prescription, combination and self-indication [1315].

The most enthusiastic sponsor of this work was Dr. Wang, current President of F.D.A. China and Director of the Chinese National Drug Evaluation Center. His support has been fundamental for this success.

\section{Conclusions}

Still in 21th century, Traditional Chinese Medicine contributing to Western science can be useful for taking decisions through its ancient and perpetual principles.

Originated from TCM parameters [16], Torsadogenic Index Management Project and Torsadogenic Traceability [11,12] will be main subject for discussion into next Washington F.D.A. Meeting agenda.

Turning results into evidence will convince Western Medicine $[17,18]$ to convoke these alternative ways for improving patients' health [19-22].

\section{REFERENCES}

[1] A. Inchauspe, "D-Phenylalanine Injection over K-1 Yongquan: A Theoretical Way of Upgrading Survival Rates in 
CPR,” BIT's 8th Annual Congress of International Drug Discovery Science and Technology (IDDST), Beijing, 23-26 October 2010.

[2] J. Wang, "Cardiovascular Safety: How to Develop Risk Assessment," BIT's 8th Annual Congress of International Drug Discovery Science and Technology (IDDST), Beijing, 23-26 October 2010

[3] A. Inchauspe, "Fármaco-Vigilancia y Muerte Súbita," Jornadas Multidiscipinarias del HINEA y C "Dr. Alejandro Korn”, Melchor Romero, La Plata, 2011.

[4] F. Desertenne, "La Tachicardie Ventriculaire a Deux Foyers Repposes Veriables,” Archives des Maladies du Coeur et des Vaisseaux, Vol. 59, 1966, pp. 263-272.

[5] M. Lanzotti and N. Citta, "Síndrome de QT Largo Adquirido: Torsade de Pointes," Univ. Buenos Aires, Universitá degli Studi de’ll Insubria, 2003. http://www.fac.org.ar/tcvc/llave/c312/lazotti.PDF

[6] E. Whitsel and P. Rautaharju, "Electrocardiography QT Interval Prolongation and Risk of Primary Cardiac Arrest in Diabetic Patients," American Diabetes Association, 2005.

[7] A. Inchauspe, "Torsadogenic Index: A Proposal to Improve Survival Rates in Cardiac Arrests Due to Prescribed Drugs,” Frontiers in Pharmacology, Vol. 3, 2012, p. 99. http://dx.doi.org/10.3389/fphar.2012.00099

[8] A. Inchauspe, "Recent Advances in Theories and Practice in Chinese Medicine,” In: Traditional Chinese Medical Criteria about the Use of Yongquan as a Life Support Maneuver, InTech, Croatia, 2011, pp. 362-366. http://dx.doi.org/10.5772/29138

[9] A. Inchauspe, “Traditional Chinese Medicine and Brain Protection: Can Its Principles Be Consistent with Western Science?" 9th IBIA International Brain Injury Association Congress, Edimburgh, 23-26 March 2012.

[10] Ling Shu, “Origin and Gathering (Gen Jie),” Chapter 5.

[11] A. Inchauspe, "Risk Management Project Applied to Torsadogenic Index,” 5th International Conference on Drug Discovery and Therapy, Dubai, 18-21 February 2013.

[12] A. Inchauspe, “Torsadogenic Index: A Vanguard Risk
Management Risk Measure into the Risk Statement Strategy,” Drug Discovery \& Therapy World Congress, Boston, 3-6 June 2013.

[13] D. Iyer, "Optimum Patient Care through Appropiate DrugSafety Monitoring,” IDDST, 2010.

[14] J. Kattwinkel and S. Niermeyer, "ILCOR Advisory Statements: Resuscitation of the Newborn Infant. An Advisory Statement from the Pediatric working Group of the International Liaison Committee on Resuscitation," Circulation, Vol. 99, 1999, pp. 1927-1938. http://dx.doi.org/10.1161/01.CIR.99.14.1927

[15] N. Swedborg, "Drug Abuse and Dependence Liability Assessment in Safety Pharmacology," BIT's 8th Annual Congress of International Drug Discovery Science and Technology (IDDST), Beijing, 23-26 October 2010.

[16] Ling Shu, "Beginning and Ending (Zhong Zhui),” Chapter 9 .

[17] F. Dessertenne, A. Fabiato and P. Courmel, "Un Chapitre Nouveau Délectrocardiographie: Les Variations Progressives de Lámplitude de L'électrocardiogramme,” Actual Cardio. Angeio. Int, Vol. 15, 1966, pp. 241-258.

[18] J. López-Valcárcel, “10 Preguntas Frecuentes Sobre el Síndrome del Qt Largo.” http://www.qtsyndrome.ch/faqsp.html

[19] B. J. Maron and N. A. Mark Estes III, "Conmotio Cordis,” New England Journal of Medicine, Vol. 362, No. 10, 2010, pp. 917-927. http://dx.doi.org/10.1056/NEJMra0910111

[20] A. Inchauspe, “Traditional Chinese Medicine K-1 Yongquan and Resuscitation: Another Kind of 'Lazarus Phenomnon',” Resuscitation, Vol. 81, No. 4, 2009, pp. 505506. http://dx.doi.org/10.1016/j.resuscitation.2009.12.009

[21] A. Inchauspe, "Sudden, Predictable and Preventable Death in Pharmacological Cardio Safety," 5th International Conference on Drug Discovery and Therapy, Dubai, 18-21 February 2013.

[22] M. Ugarte, “Detección precoz de Enfermedades Endócrino-Metabólicas en el Recién Nacido," Comunidad de Madrid. www.madrid.org 